\title{
The Tricholoma caligatum group in Europe and North Africa
}

\author{
ILKKA KYTÖVUORI
}

\begin{abstract}
KYTÖVUORI, I. 1989: The Tricholoma caligatum group in Europe and North Africa. — Karstenia 28:65-77.

Three species are recognized in the Tricholoma caligatum group in Europe: $T$. caligatum (Viv.) Ricken, T. nauseosum (Blytt) Kytöv., comb. nova, and T. dulciolens Kytöv., spec. nova. The first two species are also reported from North Africa. The East Asian T. matsutake (S. Ito \& Imai) Singer is included in T. nauseosum, which is thus an edible fungus of major international interest. The distribution of each species in the study area is mapped, and their ecology and relationships are discussed.
\end{abstract}

Ilkka Kytövuori, Department of Botany, University of Helsinki, Unioninkatu 44, SF-00170 Helsinki, Finland

In Europe (e.g. Moser 1983) the Tricholoma caligatum group is traditionally supposed to be represented by one species only. One species is also recognized in East Asia, whereas in North America Smith (1979) reports four species and four varieties of the group. However, heterogeneity is evident in the group in Europe as well, though to a smaller extent than in North America. Smith (1979) and most other North American authors, e.g. Pomerleau (1980), refer the $T$. caligatum group to the genus Armillaria. In this paper I follow the treatment of most European authors, e.g. Singer (1986), Moser (1983), Bon (1976, 1984) and Kost (1981), and refer the group to the genus Tricholoma.

\section{Material and methods}

Specimens were checked in the following herbaria (all in Europe): AQUI, ANGUC, B, BCC, BR, BRA, BP, BREM, BRNM, C, DBN, FI, G, GB, H, HBG, HOH, IB, JE, Joensuu Research Station, K, KUO, L, LG, LISU, LY, M, MA, MPU, O, OULU, PC, PAD, PAV, PERU, PRM, S, TRH, TUR, Univ. of Joensuu, UPS, VER, W (the symbols according to Holmgren et al. 1981). Some specimens were examined from the private herbaria of Dr. M. Bon, Saint Valery-sur-Somme, Dr. D. Lamoure, Lyon, and Dr. A. Riva, Balerna, and from the herba- rium of Soc. Catal. Micol. Barcelona. Types and some other specimens were also examined from $\mathrm{MICH}$.

Microscopical characters were examined with the microscope Leiz Laborlux 12 at magnifications of about 625 and 1560 . Spores, basidia and surface hyphae were drawn with the Leiz drawing tube at a magnification of 2000 . Spores were examined, measured (with an ocular micrometer) and drawn from slides showing the surface view of pieces of gills and/or hyphae from the ring or stipe top of dried basidiocarps, mounted in Melzer's reagent. Only spores in a horizontal position were measured; young, anomalous, very large and gigantic spores were excluded. When possible, both sclerospores and hyaline spores were measured. In some specimens all the hyaline spores were somewhat collapsed and then only sclerospores were measured. Length and width were measured from the same spore and the length/ width ratios were calculated for individual spores.

Basidia were drawn and measured from the same slides as the spores. Both sclerobasidia and hyaline basidia were drawn, but most of the measurements were made from sclerobasidia because the hyaline ones were often somewhat collapsed. Cap and stipe surfaces were examined from tangential sections made with a razor blade.

The illustrations are my own unless otherwise stated. 


\section{Key to species}

1 Odour strong, sweetish, like Inocybe corydalina, stipe annulate ................................................ 2

- Odour different (e.g. farinaceous or of coal gas) or lacking, stipe annulate or not ...................... Tricholoma spp.

2 Cap small (to $10 \mathrm{~cm}$ ), fuscous to blackish, \pm Mediterranean species .................................... 1. T. caligatum

- Cap small to very large (5 to $25 \mathrm{~cm}), \pm$ brownish, with or without cameous tint, temperate to boreal species ....... 3

3 Cap large, robust (to $25 \mathrm{~cm}$ ), with large, appressed scalcs, without cameous tint, spores more than $6.5 \mu \mathrm{m}$ long, with Pinus .......................................2. $T$. nauseosum

- Cap smaller (to $10 \mathrm{~cm}$ ), with numerous very thin, small scales, with cameous tint, spores less than $6 \mu \mathrm{m}$ long, with Picea 3. T. dulciolens

\section{Tricholoma caligatum (Viv.) Ricken,} Figs. 1-3, 6 .

Tricholoma caligatum (Viv.) Ricken, Blätterpilze Deutschl. 331. 1915. - Agaricus caligatus Viv., Fungh. Ital. 40, pl. 35. 1834. Armillaria caligata (Viv.) Gillet, Hymen. France. 79. 1874. - Type: not typified.

Armillaria caligata f. gracilis Bres., Icon. Mycol. 1. pl. 45. 1927. - Type: not seen.

Illustrations. Viviani (1834 pl. 35), Barla (1888 pl. 18), Bresadola (1927 pl. 45), Dähncke \& Dähncke (1980 p. 155), Bon (1976 fig. 66, 1984 fig. 66, 1987 p. 161), Soc. Catal. Micol. (1985 pl. 197), Marchand (1986: 895), Moser \& Jülich (1987 pl. III: 1), Lanzoni (1988). — Not Cetto (1980 pl. 603), Pilát \& USák (1961 figs. 62, 63), Michael et al. (1979 fig. 204, 1987 fig. 204), Korhonen (1986 p. 144), Riva (1988 pl. 68).

Pileus $3-12 \mathrm{~cm}$ wide, subumbonate to planoconvex; margin inrolled when young, outrolling with age. Surface weakly viscid when wet, somewhat shining when dry, smooth and blackish brown to fuscous in the centre, with appressed, large, dark brown scales towards the margin, at the margin often chapped, exposing the pale pileal trama, under the lens radially striate, not costate. Context thick in the centre, thin towards the margin, whitish, and fairly compact. Odour strong, just like that of Inocybe corydalina or Pholiota heteroclita. Taste sweetish-bitterish to bitter.

Lamellae close, broad, straight, sinuate, whitish, somewhat anastomosing, with some lamellulae.

Stipe $4-10 \mathrm{~cm}$ long, $1-2.5 \mathrm{~cm}$ wide, with an ascending persistent annulus 7-25 $\mathrm{mm}$ down from the lamellae. Surface below the ring concolorous with the pileus, with fairly wide, more or less transverse, blackish brown zones on a lighter background, above the ring whitish. Outer side of the ring base of the colour of the stipe below, the inner side and the edge white. Context whitish, compact, solid.

Spores $5.7-7.3 \times 4.3-5.4(-5.9) \mu \mathrm{m}$ (431 spores of 34 specimens), length/width ratio $1.20-1.40$, broadly ellipsoid, hyaline, smooth, apiculus distinct. Some sclerospores present, with thickened, hyaline to somewhat dextrinoid wall. Sclerospores somewhat smaller and relatively wider than the normal spores. Spore contents hyaline, appearing very indistinctly coagulated to guttulose in Melzer's reagent.

Basidia clavate, $27-42 \times 5.5-7.5 \mu \mathrm{m}$ (149 basidia of 28 specimens), 4-spored, with fairly large sterigmata. Sclerobasidia sparse, with thick, most often hyaline, rarely dextrinoid wall. No differentiated cystidia, but some clavate free ends of hyphae present at the gill edge.

Pileal surface formed by more or less flat hyphae 7-16 $\mu \mathrm{m}$ wide, dark brown to fuscous in Melzer's reagent. The uppermost hyphae somewhat lighter in colour, flatter and thinner-walled than the lower ones. Pigment evenly distributed, no incrustations present. Stipe surface below the ring like that of the pileus. Above the ring tufts of torulose and forked entangled hyphae and large, clavate hyphal ends with hyaline but distinct wall.

\section{Distribution and ecology}

Tricholoma caligatum seems to be a meridional species occurring most commonly around the western part of the Mediterranean, especially in South France, the eastern and southeastern parts of Spain and adjacent NW Africa (Maire 1915, Maire \& Werner 1937, Malençon \& Bertault 1975, Bon 1976, 1984, Moreno 1986). With one exception, all the rather few specimens of the present group collected from France and Spain and seen by me belong to $T$. caligatum s.str., and thus the literature records of $T$. caligatum from that region are best referred to that species.

According to Bon $(1976,1984)$, in France T. caligatum grows in acid Pinus forests, but also with Abies, Picea and Quercus suber or other evergreen Quercus species in macchia. According to the specimen labels, the most important tree species is Pinus halepensis, the other species mentioned being $P$. pinea and Quercus ilex. Bon (1976) also reports the species under Picea and Abies at higher levels in the French Central Upland, but the identity of the species there needs to be confirmed with specimens. The only specimen from there seen by me (Puy-de-Dôme, Lagoutelle, Herb. Bon 70161) was T. nauseosurn. T. caligatum s.str. from Pralognan, $1450 \mathrm{~m}$ (Herb. Lamoure), represents the highest record of the species. The northeastemmost record of $T$. caligatum s.str. is from Baden-Württemberg, West Germany ( $\mathrm{HOH}, \mathrm{OULU})$. Two of the specimens from the latter area were collected on calcareous soil. Some heterogeneity may sill exist in $T$. caligatum in Central and South Europe. 


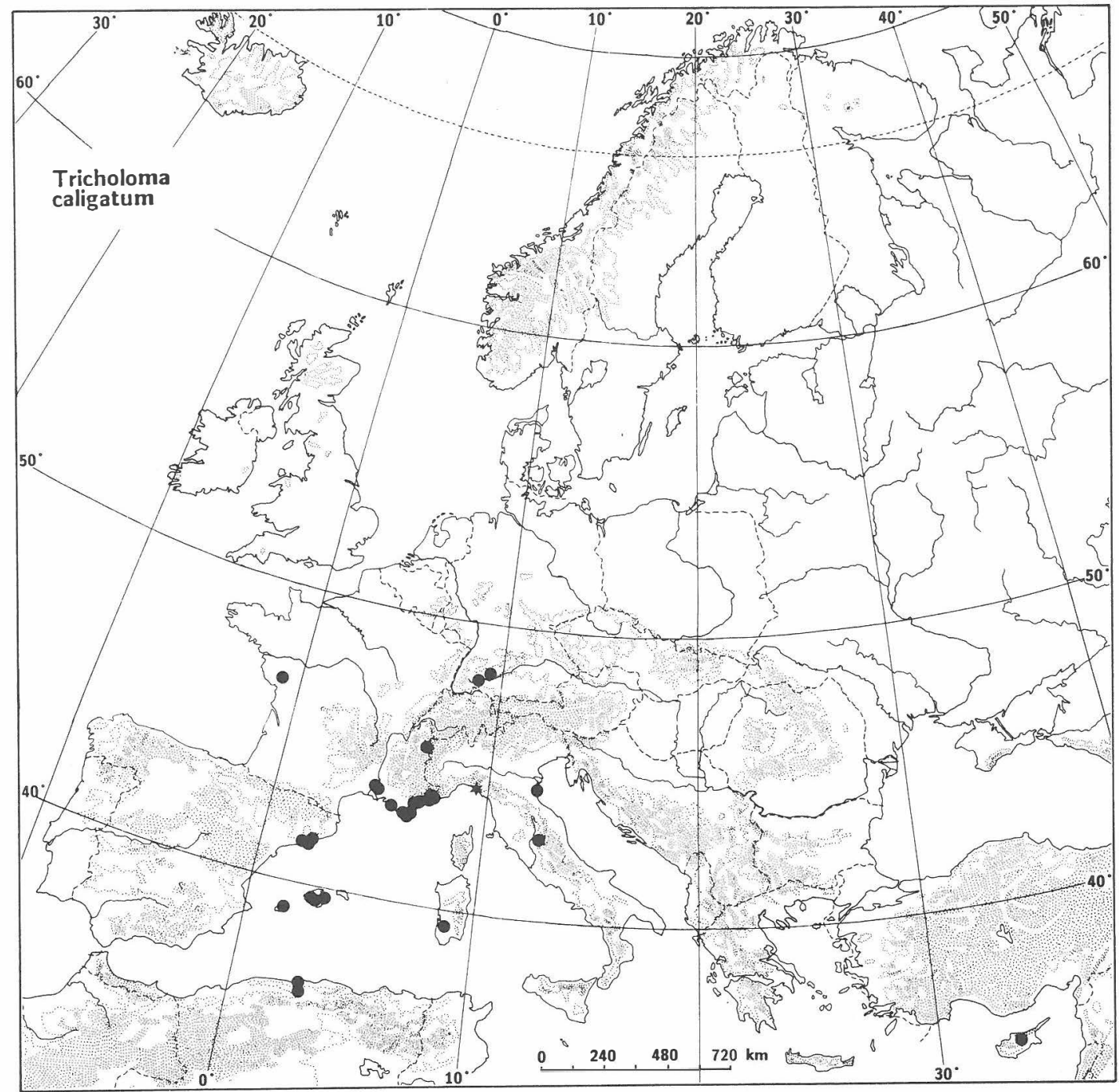

Fig. 1. Distribution of Tricholoma caligatum in Europe and adjacent North Africa according to the material examined. Asterisk indicates the type locality.

From NW Africa I have seen $T$. caligatum s.str. gathered in Pinus halepensis forests only. All the specimens from Cedrus atlantica forests were T. nauseosum. Viviani (1834) described $T$. caligatum from Liguria in Italy. From there the distribution stretches southward. The southeasternmost record is from $\mathrm{Cy}$ prus. The fact that Bresadola (1827) described the present taxon as forma gracilis possibly indicates that it is the rarer of the two species that occurs in North Italy.

The fruiting period of $T$. caligatum s.str. is long and it occurs late in the year (Fig. 5). The optimum seems to be from late October to early December, but in the warmest regions basidiocarps may possibly develop throughout the winter.

\section{Discussion}

The nomenclature of the $T$. caligatum group in Europe is unclear, apparently owing to confusion with the $T$. robustum- $T$. focale complex. Viviani's (1834) description of $T$. caligatum is accurate and Barla $(1859,1888)$ also knew $T$. caligatum well. Fries first 
mentioned the species in 1874 , but he evidently did not know it from personal field experience and his description is not exact. He reported that the odour was raphanoid rather than sweetish and placed the species near Agaricus robustus Alb. \& Schwein. (Albertini \& Schweinitz 1805). Thereafter some authors, e.g. Neuhoff (1960), erroneously applied the epithet robustus to the $T$. caligatum group. The wide variation in odour described by Smith (1979) in the T. caligatum group in North America is not found in Europe.

Agaricus caussetta Barla (Barla 1859) was included in A. caligatus by Fries (1874). However, Barla's type material (e.g., in G, JE, K, PC, S, UPS) indicates that $A$. caussetta belongs to the $T$. robustum- $T$. focale complex. I have not seen any material of Agaricus caussetta var. guttatus Barla (Barla 1859), which was included in Armillaria caligata by Bresadola (1927).

In North America the $T$. caligatum group seems to be very complicated (Smith 1979). Several species and varieties have been described. According to the descriptions and the type material, all of them seem to be different from the European taxa studied here.

\section{Specimens examined}

Germany (FRG). Baden-Württemberg: Zwiefalten, 1968 Haas (HOH, OULU); Tuttlingen, 1973 Mark (HOH), 1973 Steinmann $(\mathrm{HOH})$.

France. Alpes-Maritimes: Bendejeun; Berra; Drap; Nice; Tourrette; Villefranche, 1872-1890 Barla (FI, BP, JE, PC, UPS, S); Grasse, 1988 Kytövuori 88005 (H). Bouches-duRhône: Alpilles, 1974 Bas 6473 (L); 1974 Moser 741620 (IB); Marseille, 1966 Bequet (Herb. Bon). Savoie: Pralognan, 1971 Lamoure (Herb. Lamoure). Vaucluse: Avignon 1974 coll. unknown (C). Var: Draguignan, 1988 Kytövuori 88004 (H); Ilc de Cros, 1979 Moser 79/738 (IB); Porquerolle, 1980 Moser $80 / 572$ (IB); Toulon, 1959 Koopmans \& Velh (L). Vendée: Forĉt de Mervent, 1974 Kerhoas (ANGUC).

Spain. Barcelona: Cabrils, 1978 Mena (MA); Entre Cerelló y Bruguers, 1972 Llimona (MA); Torrelles de Llobregat, 1971 Gabriel et Aizpurua (BCC); St Fcliu de Llobregat, 1983 Llimona (MA); no date Tabares (Herb. Catal. Micol.). Ibiza: San Juan-Cala Vicente, 1973 Finschow et Grauwinkcl (BREM). Mallorca: Gerhardt 1976 (B); Cala Mezquida; Lluch, 1980 Knudsen (C); Palma de Mallorca, 1977 Rey (MA).

Italy. Emilia: Ravenna (Lanzoni 1988). Liguria: Chiávari (Viviani 1834). Sardinia: Arbus, 1980 Fantini (AQUI). Umbria: Perugia, 1983 Rinaldi (PERU).

Cyprus. 1965 Zyngas (K).

Algeria. Atlas de Blida, 1912 Maire (MA); Ager, Forêt de Bainem, 1920 Maire (MPU); Sidi-Ferruch, 1939 Maire (MPU).

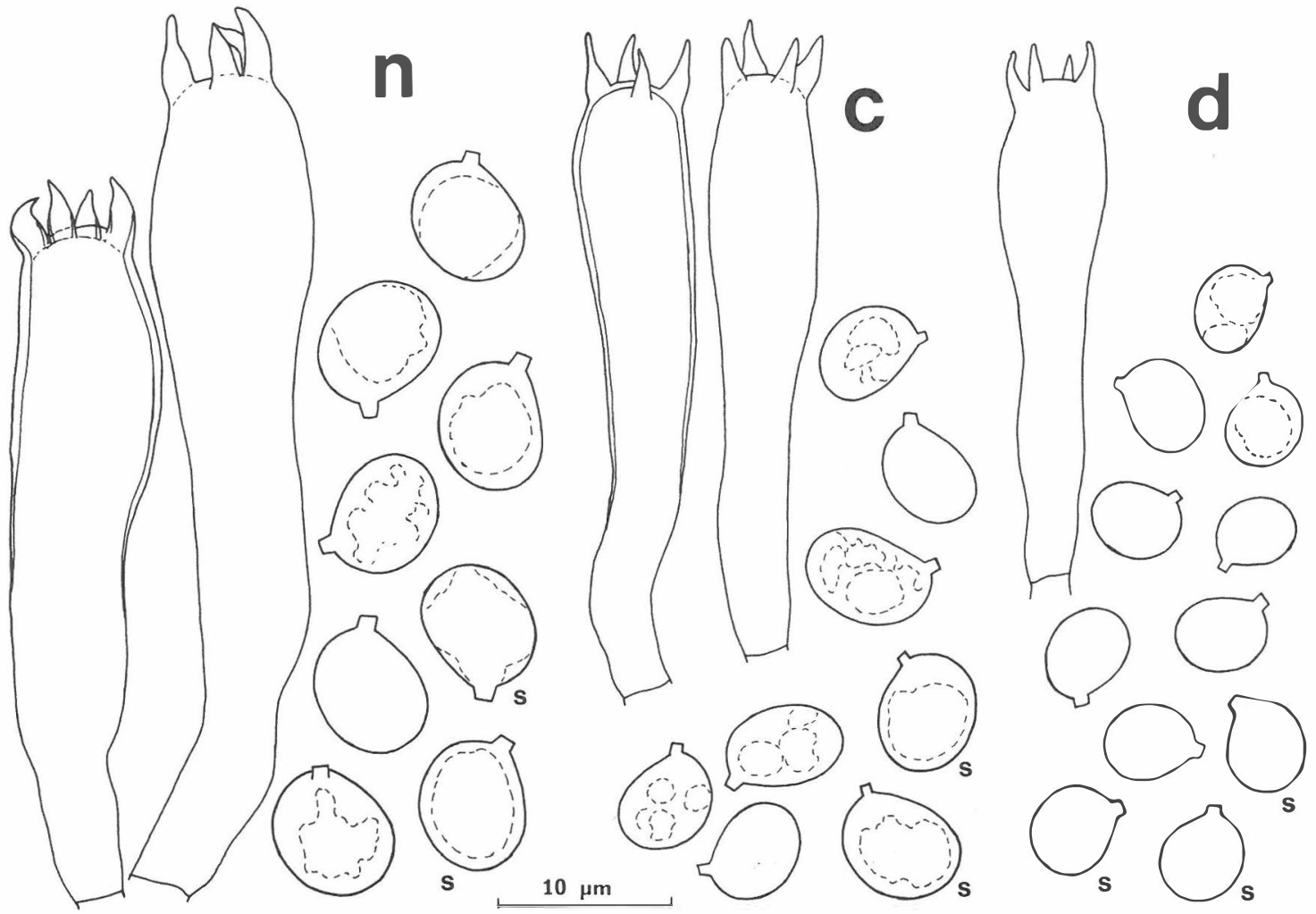

Fig. 2. Basidia and spores. - n) Tricholoma nauseosum 1985 Vesterberg (S), c) T. caligatum 1980 Fantini (AQUI), d) $T$. dulciolens 1984 Kaufmann (holotype, H), s indicates the sclerospores. Scale $\times 2000$. 


\section{Tricholoma nauseosum (Blytt) Kytövuori,} comb. nova, Figs. 2-4, 7

Armillaria nauseosa Blytt, Vidensk. Selsk. Skrift. 6:22. 1905. - Holotype: Norway, Akershus, Oslo, Sognsvand, 4.IX.1887 A.N. Blytt (O).

Armillaria matsutake S. Ito \& Imai, Bot. Mag. 39:326. 1925. Tricholoma matsutake (S. Ito \& Imai) Singer, Ann. Mycol. Berl. 41:77. 1943. - Type: not seen.

Armillaria goliath auct. vix (Fr.) Lundell \& Nannfeldt, Fungi Exs. Suec. 1706. 1949. - Agaricus focalis var. goliath Fries, Mon. Armill. Suec. 5. 1854. - Type: not seen.

Illustrations: Šmarda (1950), Pilát et Ušák (1961 figs. 62, 63), Pace (1978 p. 135), Michael et al. (1979 fig. 204, 1987 fig. 204), Svrčck et al. (1981 p. 133), Korhonen (1986 p. 144), Riva (1988 pl. 68), all s.n. T. caligatum; Imazeki \& Hongo (1965 pl. 9) and Pace (1978 p. 135), s.n. T. matsutake.

Pileus 6-20(-30) $\mathrm{cm}$ wide, convex to planoconvex, subumbonate, with margin inrolled when young, outrolling with age, bent slightly downwards even in the oldest basidiocarps. Surface weakly viscid when wet, somewhat shining when dry, radially fibrillose, often with large appressed scales, at the margin often chapped, exposing the pale pileal trama, not costate. The centre brown to light brown (without red-brown tints), towards the margin lighter. Context thick in the centre, somewhat thinner towards the margin, white, compact. Odour strong, sweetish, like that of Inocybe corydalina or Pholiota heteroclita. Taste very mild, pleasant.

Lamellae close, broad, straight, emarginate, white, hardly anastomosing, with several lamellulae.

Stipe 5-20(-25) cm long, $1.5-2.5 \mathrm{~cm}$ wide, of even thickness or slightly tapering or enlarging downwards, most often curved and deeply radicating, the hypogeal part sub-bulbous to slightly tapering, not root-like. A patent or slightly hanging, persistent annulus on the upper part of the stipe, 5$15(-30) \mathrm{mm}$ downwards from the lamellae. The stipe below the ring weakly viscid, concolorous with the pileus, with fairly broad, obscure, more or less transverse brown zones on the lighter background, above the ring pure white, somewhat pruinose. Context solid, very compact, white.

Spores 6.6-8.4(-9.1) x 5.0-6.3 $\mu \mathrm{m}$ (742 spores of 60 specimens), length/width ratio $1.20-1.40$, broadly ellipsoid, hyaline, smooth, apiculus distinct, about $1 \times 1 \mu \mathrm{m}$. Some sclerospores nearly always present, with somewhat thickened and most often dextrinoid wall, indextrinoid sclerospores rarer. Sclerospores somewhat smaller and relatively wider than the hyaline spores. Spore contents hyaline, appearing very indistinctly coagulated to guttulose in Melzer's reagent, in sclerospores with more distinct large guttula.

Basidia clavate, $35-50 \times 6.5-9 \mu \mathrm{m}$ (185 basidia of 51 specimens), 4-spored, with large sterigmata.

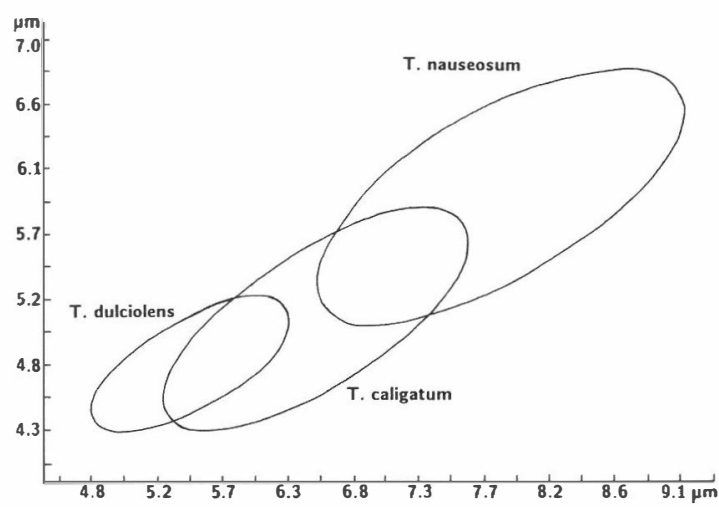

Fig. 3. Diagram showing the spore size of the species above. The lines are drawn on the basis of scatter diagrams, and contain near $95 \%$ of the spores measured of each species $(T$ dulciolens 205 spores, 14 specimens, $T$. caligatum 431 spores, 34 specimens, $T$. nauseosum 742 spores, 60 specimens). $x$ axis: length of spores. y axis: width of spores.

Some more or less thick-walled sclerobasidia nearly always present, but sparse, with more or less dextrinoid wall. No differentiated cystidia, but most often the gill edge crowded with narrow, torulose, somewhat projecting free ends of hyphae; mainly sterile but some solitary basidia present.

Pileal surface formed by a layer of flat and very thin-walled, 7-25- $\mu \mathrm{m}$-wide hyaline hyphae and light brownish, somewhat narrower hyphae below. The light brownish, structurally very indistinct surface view differs clearly from the well-defined dark network of the pileal surface of $T$. caligatum. Under the microscope, the colour difference between $T$. nauseosum and $T$. caligatum is clear even in basidiocarps looking almost identical in colour to the naked eye. Pigment evenly distributed, no incrustations present. Stipe surface below the ring like that of the pileus. Above the ring a loose layer of torulose, entangled, thin-walled, narrow hyphae and dense sphaero-pedunculate hyphal ends, yellowish in Melzer's reagent, much denser and smaller than those of $T$. caligatum or $T$. dulciolens.

\section{Distribution and ecology}

Tricholoma nauseosum occurs in dry Pinus sylvestris forests in the whole of Fennoscandia. It is not uncommon in Finnish and Swedish Lapland in northern boreal, fairly open, dry pine forests rich in lichens (but commonly heavily grazed by reindeer), on a very thin humus layer above glaciofluvial sand or glacial 


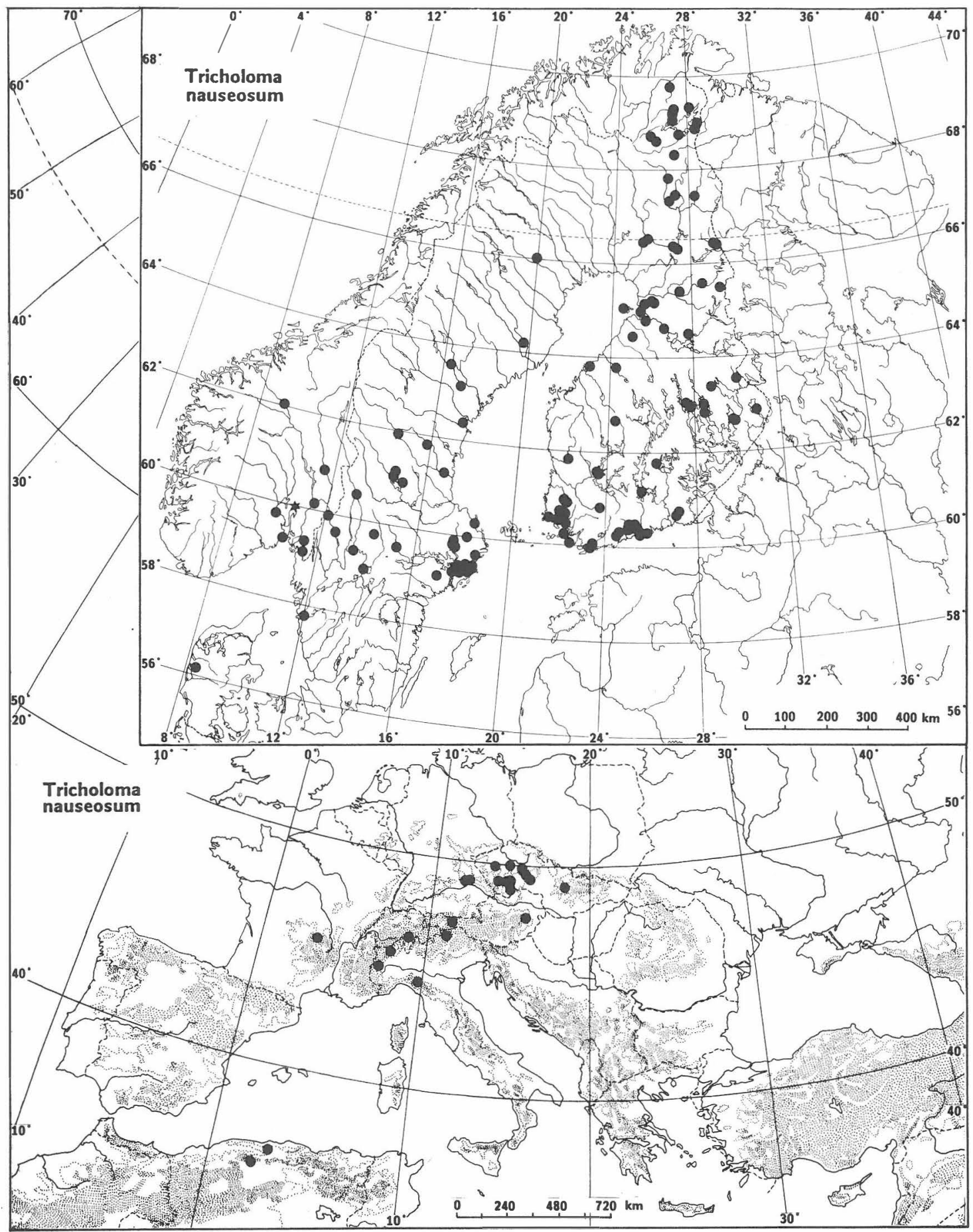

Fig. 4. Distribution of Tricholoma nauseoswn in Europe and adjacent North Africa according to the material examined. Note the larger scale of Fennoscandia and Denmark. Asterisk indicates the type locality. 
till. It occurs less frequently in open rocky pine forests with thin mineral soil. Only very exceptionally does it occur in pure spruce forests. The habitats are acid and poor in nutrients. The species becomes much rarer towards the south.

The northern tendency is not seen clearly on the map of the distribution (Fig. 4), owing to the weaker collecting activity in the north. This large and conspicuous fungus is of interest to the public and a large proportion of the herbarium collections in the Fennoscandian museums have been made by ordinary mushroom gatherers rather than mycologists. Thus knowledge of the fungus is concentrated in the environs of the university towns and biological stations. $T$. nauseosum is so clearly the commonest species of the group in Fennoscandia that the records of "T. caligatum" in the Fennoscandian literature (e.g. Gulden 1969, Ulvinen 1975, Ulvinen et al. 1981, Korhonen 1986) are normally referable to T. nauseosum. One exception is in Medelpad, Sweden, where only one of the four known records (one in $\mathrm{H}$, three given by Eriksson et al. 1985) belongs to $T$. nauseosum, while two others belong to $T$. dulciolens and one is unknown (no specimen).

Outside Fennoscandia $T$. nauseosum is fairly rare in Europe, being known from mountain areas in Czechoslovakia, the southern part of West Germany, Austria, Switzerland and North Italy. The species apparently occurs in the mountains towards the southeast, but no specimens exist. From France I have seen one specimen, viz. from the Central Upland. In the lowlands of Central and South Europe, T. nauseosum seems to be lacking (cf. Krieglsteiner 1981, Kreisel 1987). In Estonia the species is reported as rare (Shtshukin 1981, Urbonas et al. 1986). The distribution in the boreal zone between Fennoscandia and East Asia is unknown. In Central Europe it also grows in dry forests of Pinus sylvestris (Pilát et Usák 1961, Michael et al. 1987).

From North Africa I have seen five T. nauseosum specimens from the Atlas Mountains south of Alger in Algeria, all associated with Cedrus atlantica. According to Malençon et Bertault (1975), "T. caligatum" is rather common in forests of $C$. atlantica in Moyen Atlas in Morocco. The tree species and the size of the fruit bodies (reportedly up to $20 \mathrm{~cm}$ wide) supports the inclusion of these records in $T$. nauseosum. In Japan the species occurs mainly in forests of Pinus densiflora (Zeller \& Togashi 1934, Tominaga 1978).

In the boreal zone Tricholoma nauseosum produces fruit bodies fairly early in the mushroom season (Fig. 5), most actively in late August and early September, about one month earlier than the fruiting peak of most other Tricholoma species in dry pine forests in Fennoscandia. In most years such habitats are too dry at that time, and then the basidiocarp production is very poor. The capacity of the species to postpone its fruiting when the weather is unsuitable is evidently limited. Thus its fruiting is very occasional and interruptions of several years are usual. In the north the basidiocarp production seems to be somewhat less irregular than farther south in Fennoscandia.

In Central Europe also, the species produces fruit bodies early in the year, some specimens being gathered as early as July. The North African specimens were collected from June to December. In Japan the main fruiting period is October-November, but the species may also produce basidiocarps in May and June (cf. Pilát \& Usák 1961). In areas south of Fennoscandia the night moisture may allow earlier fruiting; in the north the nights in June and early July are too short to give enough moisture.

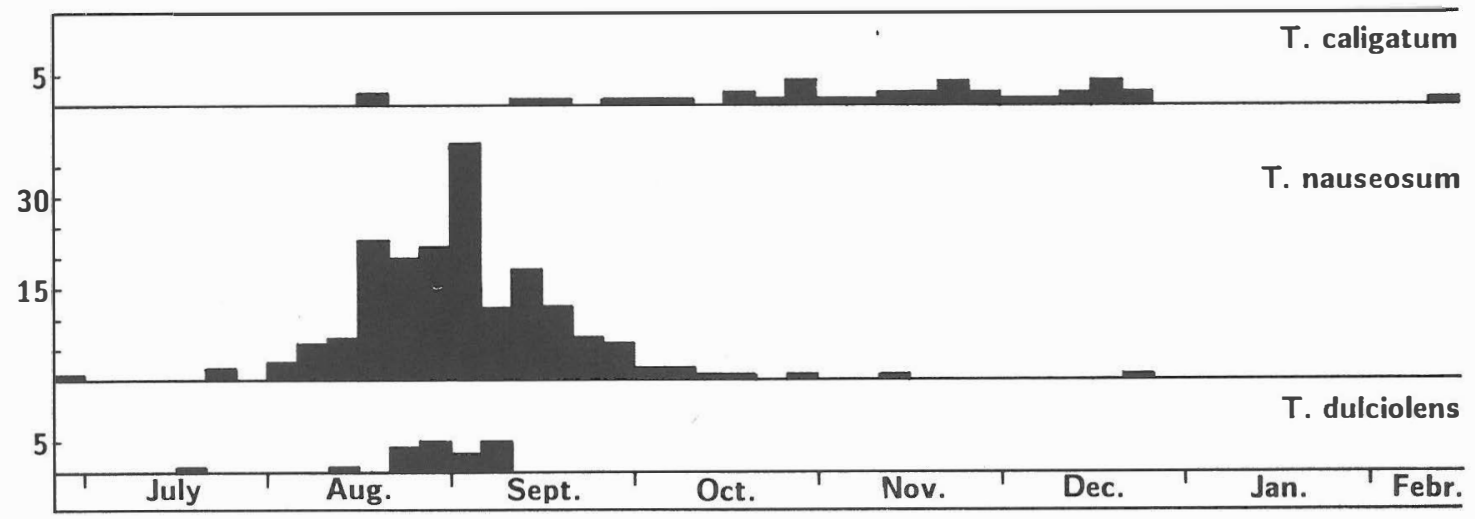

Fig. 5. Fruiting periods of the species above according to the specimens examined. $x$ axis: the season from 26.VI. to 7.II. divided in pentads. y axis: number of specimens collected in each pentad. 


\section{Discussion}

Blytt's (1905) description of Armillaria nauseosa is not very striking and this may be the reason why the name has been overlooked. Fortunately the type specimen exists and so at least it is certain that the name belongs to the present species. Blytt himself suspected that his species might be identical with Agaricus roborosus Britz. (Britzelmayr 1895, 1898, see also Stangl \& Bresinsky 1967), but the original description of the latter indicates that it is clearly a different species.

The name Agaricus focalis var. goliath Fr. (Fries 1854) was applied to the present species by Lundell \& Nannfeldt (1949), as Armillaria goliath. However, Fries (1854) did not mention the peculiar odour. Later (Fries 1874), he recognized both Agaricus focalis var. goliath and A. caligatus, but did not compare them with each other at all. Evidently Bon (1976) was right in placing var. goliath in the T. robustum$T$. focale complex.

After examining the original description and the black and white photographs in Zeller \& Togashi (1934), Pilát (1950) reported that the East Asian Armillaria matsutake S. Ito \& Imai was identical with the present species. I have not seen type material of A. matsutake, but some later Japanese specimens in European herbaria and two fresh, young fruit bodies brought from Japan by Mr. A. Sirkiä and Mr. J. Auramo (now specimen in $\mathrm{H}$ ) agree well with $T$. nauseosum, and the coloured figure in Imazeki \& Hongo (1965) represents a most typical T. nauseosum. According to Ito \& Imai (1925), the clearest difference between $A$. matsutake and A. caligata is that between the enlarged stipe base of the former and the tapering stipe of the latter. In fact, the stipe base of $T$. nauseosum may taper downwards, but more often it is of even thickness or somewhat enlarged. In this case the characters seem to lack taxonomic value.

In North America $T$. ponderosum (Peck) Singer is probably the closest ally of $T$. nauseosum.

In Japan T. nauseosum (s.n. T. matsutake) is traditionally a highly esteemed edible fungus (cf. Tominaga 1978). In South Europe also, the species, together with $T$. caligatum, is recognized as edible and has commercial value. In Fennoscandia its food value has not been understood, possibly owing to its northern distribution and rarity in southern Fennoscandia, where most mushroom pickers live. However, in suitable conditions it may be locally very productive and thus valuable.

\section{Specimens examined}

Finland. Varsinais-Suomi: Dragsfjärd (H), Masku (TUR), Mynämäki (TUR), Naantali (TUR), Parainen (TUR), Raisio
(IUR), Taivassalo (TUR), Turku (H, 2 ex. TUR), Vahto (TUR). Uusimaa: Espoo (2 ex. H), Porvoo rural communc (4 ex H), Sipoo (3 ex. H), Tammisaari (2 ex. H), Tuusula (3 ex. H). Etelä-Karjala: Vehkalahti (3 ex. H). Satakunta: Eura (TUR), Kankaanpää (TUR), Yläne (7 ex TUR). Etelä-Häme: Asikkala (H, 4 ex. KUO, O), Joutsa (TUR), Tammela (H), Yläjärvi (OULU, TUR). Pohjois-Häme: Ähtäri (H). PohjoisSavo: Juankoski (H, KUO), Siilinjärvi (H, 3 ex. KUO), Tuusniemi (KUO). Pohjois-Karjala: Ilomantsi (Univ. of Joensuu), Kontiolahti (2 ex Univ. of Joensuu, Joensuu Research Station); Lieksa (Joensuu Research Station), Nurmes (H, KUO). Keski-Pohjanmaa: Kokkola (OULU), Toholampi (OULU), Vihanti (H). Kainuu: Paltamo (H), Suomussalmi (H). Oulun Pohjanmaa: Hailuoto (2 ex. OULU), Haukipudas (5 ex. OULU), Oulu (OULU), Oulunsalo (OULU), Pudasjärvi (H), Tymävä (3 ex. OULU), Utajärvi (OULU). Perä-Pohjanmaa: Rovaniemi (TUR), Rovaniemi rural commune, Autti (2 cx. H), Hirvas (TUR), Pahtaja (BP). Koillismaa: Kuusamo, Oulanka (8 ex. H, 6 ex. OULU), Taivalkoski (OULU). Sompion Lappi: Savukoski (H), Sodankylä (3 ex. H). Inarin Lappi: Inari, Kaamanen (H, 2 ex. TUR), Kakslauttanen $(\mathrm{H})$, Kessi $(\mathrm{H})$, Lemmenjoki $(\mathrm{H})$, Menesjoki $(\mathrm{H})$, Nellimö $(\mathrm{H})$, Suojanpcrä (H), Syysjärvi (IB), Ukonjärvi (H). Utsjoki, Kevo (2 cx. OULU, UPS, 18 ex. TUR).

Sweden. Bohuslän: Romelanda (B, GB, S). Västergötland: Amnehärad (GB). Värmland: Arvika (S), Färnebo (3 ex. S), Karlstad (S), Kristinehamn (UPS), Norra Ny (3 ex. GB, S, UPS). Södermanland: Botkyrka (2 ex. S), Gryt (S), Huddingc (S), Nacka (S), Salcm (S), Tyresö (S). Uppland: Alsike (UPS), Bondkyrka ( 2 ex. UPS), Börje (UPS), Börstel (UPS), Danmark (PRM, S, 3 ex. UPS, W), Faringe (S), Gustavsberg (S), Lidingö (S), Lillsjönäs (S, UPS), Möja (S), Riala (S), Rydbo (S), Uppsala (UPS), Vaxholm (S), Värmdö (S), Vänge (S), Östra Ryd (S). Västmanland: Lindesberg (UPS). Dalarna: Mora (S), Orsa (S), Rättvik (UPS). Hälsingland: Färila (S), Mo (S, UPS). Medelpad: Selånger (UPS). Ångermanland: Långscle (UPS), Ramsele (UPS). Härjedalen: Sveg (S). Västerbotten: Vindeln (UPS). Lule Lappmark: Jokkmokk, Norden (IB).

Norway. Østfold: Halden (2 ex. O), Rakkestad (2 ex. O). Akershus og Oslo: Nes (O), Oslo sce type. Hedmark: Eidskog (O), Elverum (O). Oppland: Dovre (O). Buskerud: Hokksund (O). Vestfold: Sem (O).

Denmark.Jutland: Hoverdal Plantage, 1985, Søchting (C).

Czechoslovakia. Bohemia: Bechyně (PRM), Čechtice (PRM), Př́ibram (PRM), Sobæslav (PRM), Světlá nad Sázavou (PRM), Trěbǒn (PRM), Vodñany (2 Ex. PRM). Moravia: Město Ždár (BRNM, 2 ex. PRM), Veverská Bítyška (BRNM). Slovakia: Sutovce (BRA).

Germany (FRG). Bavaria: Hauzenstein, 1920, 1948 Killermann (M); Regensburg, 1920 Killermann (M).

Austria. Nieder-Østerreich: Scheibling-Kirchen, 1931 Jusa (W). Tirol: Fritzens, 1932 Moser 52/118 (M).

Switzerland. Ticino: Gribbio, 1980 Riva (Herb. Riva).

Italy. Emilia: Borgo Val di Taro, 1988 Ohenoja (OULU). Piemonte: Riva-Valdobbia, 1896 Crestio (S); Val Chisonc, 1966 Cimino (VER). Trentino: Appianum, 1924 Schmoranzer, Herb. Bresadola 71 (M).

France. Puy-de-Dôme: Lagoutelle, 1970 Marti (Herb. Bon 70161).

Algeria. Atlas Mountains: Blida 1911, 1912 Maire (G, K, S, UPS); Teniet el Had, 1917 Maire (MPU).

Japan. Ishiyana-Hiratsu-cho, Oko. 1954 Hongo herb. (K); Kyoto, Iwakura, 1950 Hamada (L); Singa, Minakuchi-cho, 1988 Ohta (H); Tokyo, no date or collector (PC); two specimens bought as an edible fungus in Japan: 1959 Blacker \& Evans (K), 1986 Sirkiä \& Auramo (H). 
3. T. dulciolens Kytövuori, spec. nova, Figs. 2, $3,8,9$

Pileus 5-10 cm latus, subumbonatus vel convexus, margine involuto dein recto; leviter viscidus, centro brunneolo, margine pallido, omnino dilute carneus; cute pilei squamis tenuibus, fibrillosis, agglutinatis, fuscis pellita; lamellis confertis albidis, stipite longo, solido, annulato. Odor fragrans sicut in $T$. nauseoso vel Inocybe corydalina, sapor subamarus. Sporae $4.8-6.1 \times 4.1-5.0 \mu \mathrm{m}$, subglobosae, hyalinae, inamyloideae. In silvis coniferis (Picea abies). Augusto, Septembri.

Holotypus: Sweden, Medelpad, Borgsjö, Harån/Lombäckcn, Granbodåsen, Picea-Vaccinium myrtillus forest with Pinus and Betula. 22.VIII.1984 H. Kaufmann (H, isotypus in $\mathrm{K})$.

Pileus $5-10 \mathrm{~cm}$ wide, subumbonate to convex, with margin inrolled when young, outrolling with age. Surface weakly viscid when wet, somewhat shining when dry, brown to light brownish in the centre, fairly light-coloured towards the margin, with numerous small, very thin, agglutinated scales formed by an entangled network of dark brown fibrils, not costate. The whole surface with a weak pinkish to flesh-coloured tint. Sometimes the scales absent or nearly so, then the pileus light brownish flesh-coloured and under the lens very finely radially striate. The whitish trama visible between the scales, but the surface at the margin not radially chapped as in $T$. nauseosum. Context fairly thin and loose, whitish. Odour strong, like that of $T$. nauseosum, Inocybe corydalina or Pholiota heteroclita. Taste sweetish-bitterish.

Lamellae fairly close, straight, sinuate, whitish, somewhat anastomosing, with some lamellulae.

Stipe 6-15 cm long, longer than the width of the pileus, $1-1.5 \mathrm{~cm}$ wide, of even thickness, most often straight. A persistent but fairly inconspicuous annulus on the upper part of the stipe, $12-30 \mathrm{~mm}$ from the lamellae, relatively lower down than in $T$. nauseosum. The stipe below the ring concolorous with the pileus, with dark brown, thin appressed scales (not zones) on the lighter background; above the ring whitish (not pure white). Context solid, fairly loose, whitish.

Spores 4.8-6.1 x 4.1-5.0 $\mu \mathrm{m}$ (205 spores of 14 specimens), length/breadth ratio 1.14-1.30, subglobose to broadly ellipsoid, hyaline, smooth with distinct apiculus. Some dextrinoid sclerospores present, indextrinoid ones sparse. Spore contents hyaline appearing very indistinctly coagulated to guttulose in Melzer's reagent.

Basidia clavate, $27-35 \times 6-7 \mu \mathrm{m}$ (35 basidia of 8 specimens), 4-spored. Sclerobasidia sparse, with somewhat thickened dextrinoid wall, hyaline-walled sclerobasidia rarer. No differentiated cystidia.

Pileal surface formed by a layer of 7-15- $\mu \mathrm{m}$-wide, somewhat flat thin-walled, hyaline hyphae and somewhat narrower brown hyphae below. The structure resembles that of $T$. caligatum, but is not so dark, the cell wall is thinner and some hyaline hyphae exist above the darker ones. The pigment is evenly distributed; no incrustations occur. Stipe surface below the ring like that of the pileus, above the ring parallel, tubular, white hyphae with loose scale-like fascicles of torulose entangled hyphae and fairly large, more or less patent, clavate end-cells, distinct in Melzer's reagent.

\section{Distribution and ecology}

Tricholoma dulciolens occurs in Fennoscandia in dryish upland-type forests of Picea abies or mixed forests of $P$. abies and Pinus sylvestris, rarely in pure $P$. sylvestris forests. The moss cover in such forests is continuous and often thick. The species seems to occur sparsely in its habitats. It is rare, but is probably distributed throughout the whole of Fennoscandia in the range of Picea abies.

The species is probably not exacting as regards the acidity or nutrient content of the habitat. Although most of the Fennoscandian specimens are from more or less rich areas, it seems that they have been growing in less fertile places.

Outside Fennoscandia $T$. dulciolens is known to occur in Czechoslovakia and Switzerland. The $T$. caligatum group as a whole is reported to be rare in Czechoslovakia. Of the 15 Czechoslovakian specimens of the group in PRM seen by me, four were $T$. dulciolens, $10 \mathrm{~T}$. nauseosum and one too young. All the four $T$. dulciolens specimens were from the same district, but from different places. Favre's (1960) " $T$. caligatum" records from spruce forests in Parc National Suisse, in Graubünden, Switzerland, are possibly best referred to $T$. dulciolens.

The material of $T$. dulciolens is scanty, but this species also seems to produce basidiocarps early in the mushroom season and the fruiting period is short (Fig. 5). All but one of the specimens have been gathered in late August or early September.

\section{Discussion}

In Europe Tricholoma dulciolens can be easily recognized by its habitat, size, colour and small, relatively wide spores. It greatly resembles the American taxon Armillaria caligata var. occidentalis A.H. Smith (1979), described from Idaho (Holotype: U.S.A. Idaho, Payette National Forest, prope Government Creek, 23.VIII.1958, A.H. Smith 60431; MICH). 


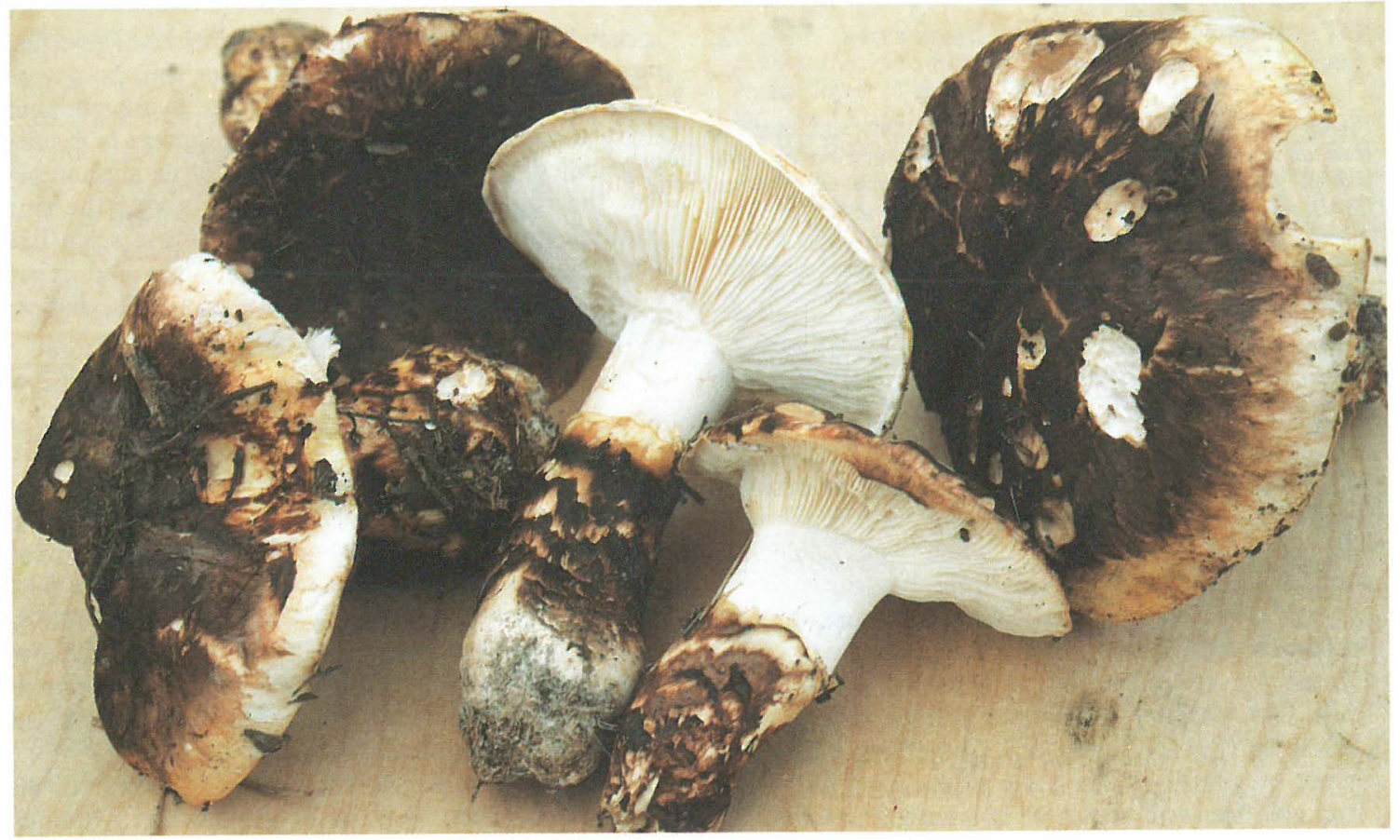

Fig. 6. Tricholoma caligatum, France, Alpes Maritimes, Grasse, lc Tignet-St-Cézaire-sur-Siagne, 1988 Kytövuori 88005 (H).

Among the many taxa of the group in North America, that variety is the only one occurring in spruce or spruce-fir forests; the others occur in pine, hemlock or broad-leaved forests. However, in comparison with $T$. dulciolens, var. occidentalis seems to have a markedly darker colour, more roughly fibrillose cap surface and relatively narrower and slightly larger spores $(5.4-6.3 \times 4.5-4.8 \mu \mathrm{m}$ measured from the type, 5-6.5 $\times 4-5 \mu \mathrm{m}$ according to Smith). Therefore, I have thought it best to describe the European material as a new species. Its relationship to var. $o c$ cidentalis needs further research with more material.

\section{Specimens examined}

Finland. Pohjois-Häme: Saarijärvi, Kolkanlahti, 1972 Ulvinen (H, OULU). Pohjois-Karjala: Ilomantsi, the nature reserve of Koivusuo, 1985 Ohenoja (OULU). Kainuu: Paltamo, Mustolanvaara, 1981 Kytövuori 81899 (H), Sotkamo, Kontinjoki, 1981 Kytövuori 81917 (H). Perä-Pohjanmaa: Rovanicmi rural commune, Taipale, 1981 Kytövuori 811032 (H). Koillismaa: Kuusamo, the Oulanka National Park, 1983 Seppänen (H), 1988 Ruotsalainen (KUO), Salla, Pyhätunturi, Kaunisharju,
1988 Kytövuori 88001 (H). Sompion Lappi: Savukoski, Tanhua, 1988 Kytövuori $88002(\mathrm{H})$.

Sweden. Södermanland: L. Malma, Malmköping, 1981 Hedsten (S). Uppland: Funbro, Bärby, 1936 Lundell (UPS); Munsö, 1943 Suber (S). Dalarna: Älvdalen, Åscn, Valsbo, 1980 P. \& I. Kytövuori 80504 (H). Medelpad: sec typc; Midskogsberget, 1977 Lindbcrg (UPS). (TRH).

Norway. Sör-Tröndelag: Strinda, Jonsvatnet, 1967 Östby

Czechoslovakia. Bohemia: Konstantinovy Lázně: Kokašíce, 1963, Krasíkov, 1966; Loučky, 1970; Zádub, 1972 all Pilát (PRM).

Switzerland. Graubünden: Davos-Platz, 1967 Peter (PRM).

Acknowledgements. I thank Prof. Tcuvo Ahti, Ph.D., and Mr. Tauno Ulvinen, Lic.Phil., for valuable suggestions regarding the manuscript. I am also indebted to Dr. Harri Harmaja, Mr. Roland Skytén, M.Phil., and Mrs. Esteri Ohenoja, Lic.Phil., for arranging the loans, to Mr. A. Ohta, Mr. A. Sirkiä and Mr. J. Auramo for the dried and fresh $T$. matsutake specimens from Japan, and to Mrs. Anna Damström, M.A., and Mrs. Marja Kaila, M.A., for the English and Latin revisions. 


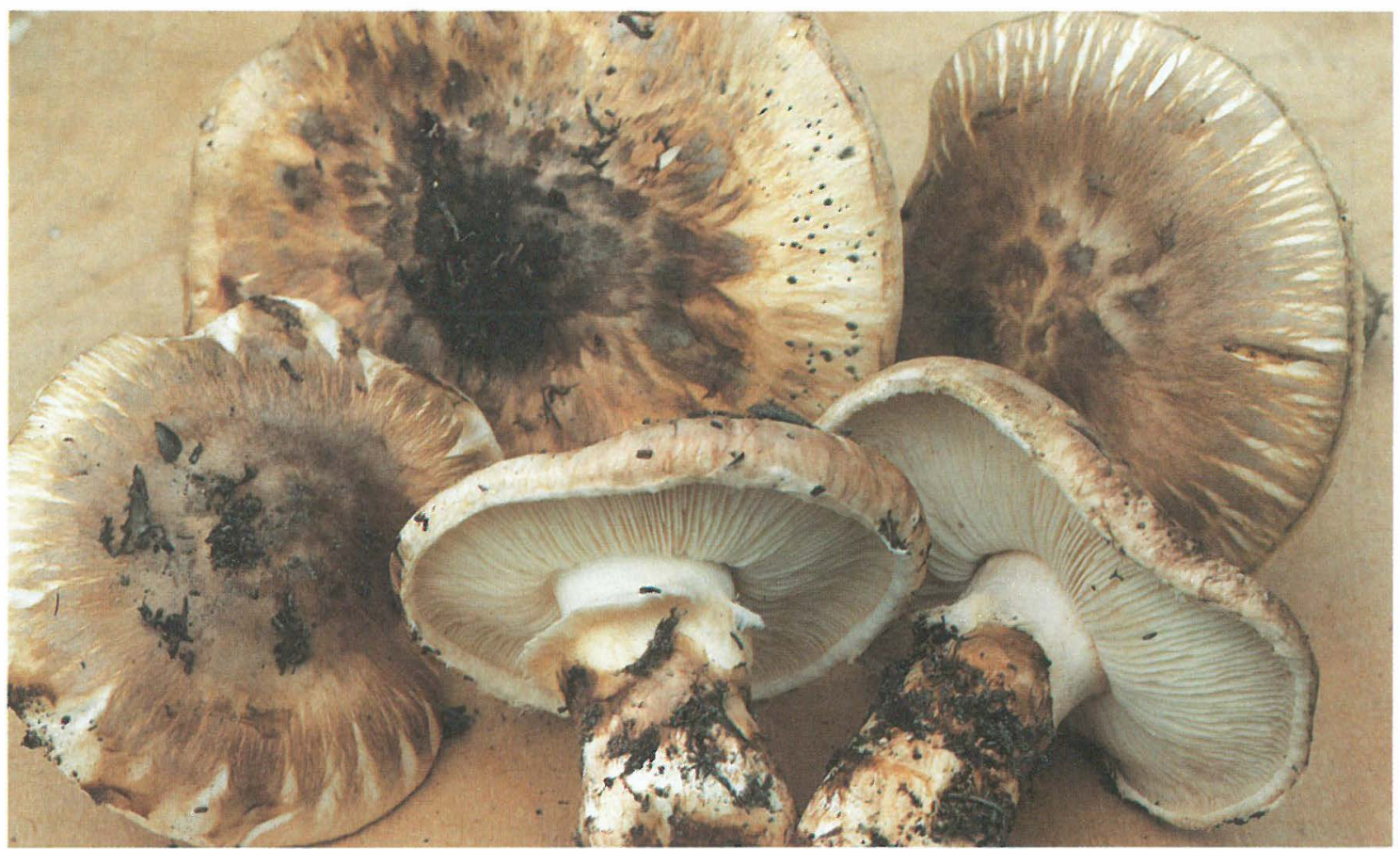

Fig. 7. Tricholoma nauseosum, Finland, Sompion Lappi, Sodankylä, Madetkoski, 1988 Kytövuori 88003 (H).

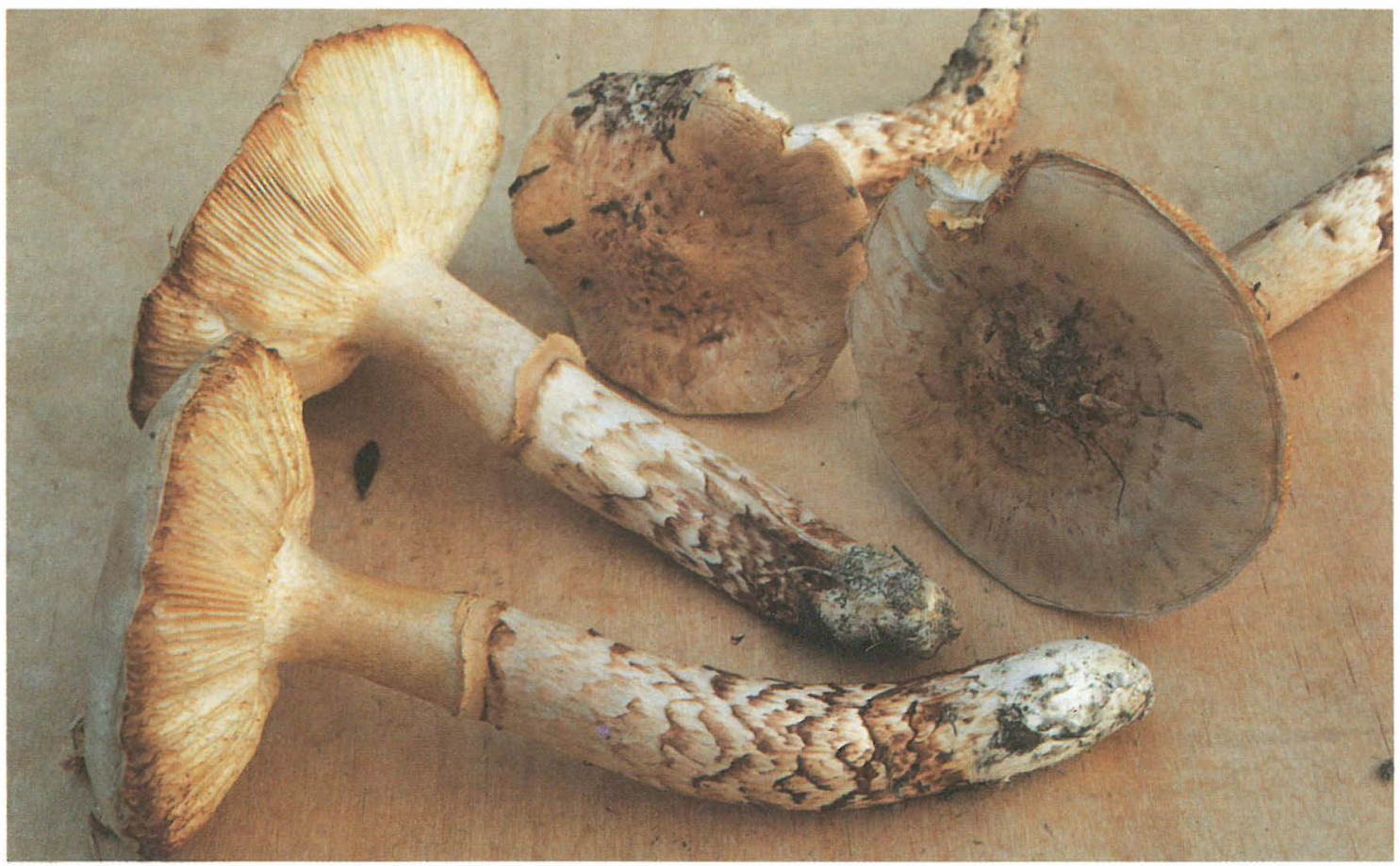

Fig. 8. Tricholoma dulciolens, Finland, Koillișmaa, Salla, Pyhätunturi, Kaunisharju, 1988 Kytövuori 88001 (H). 


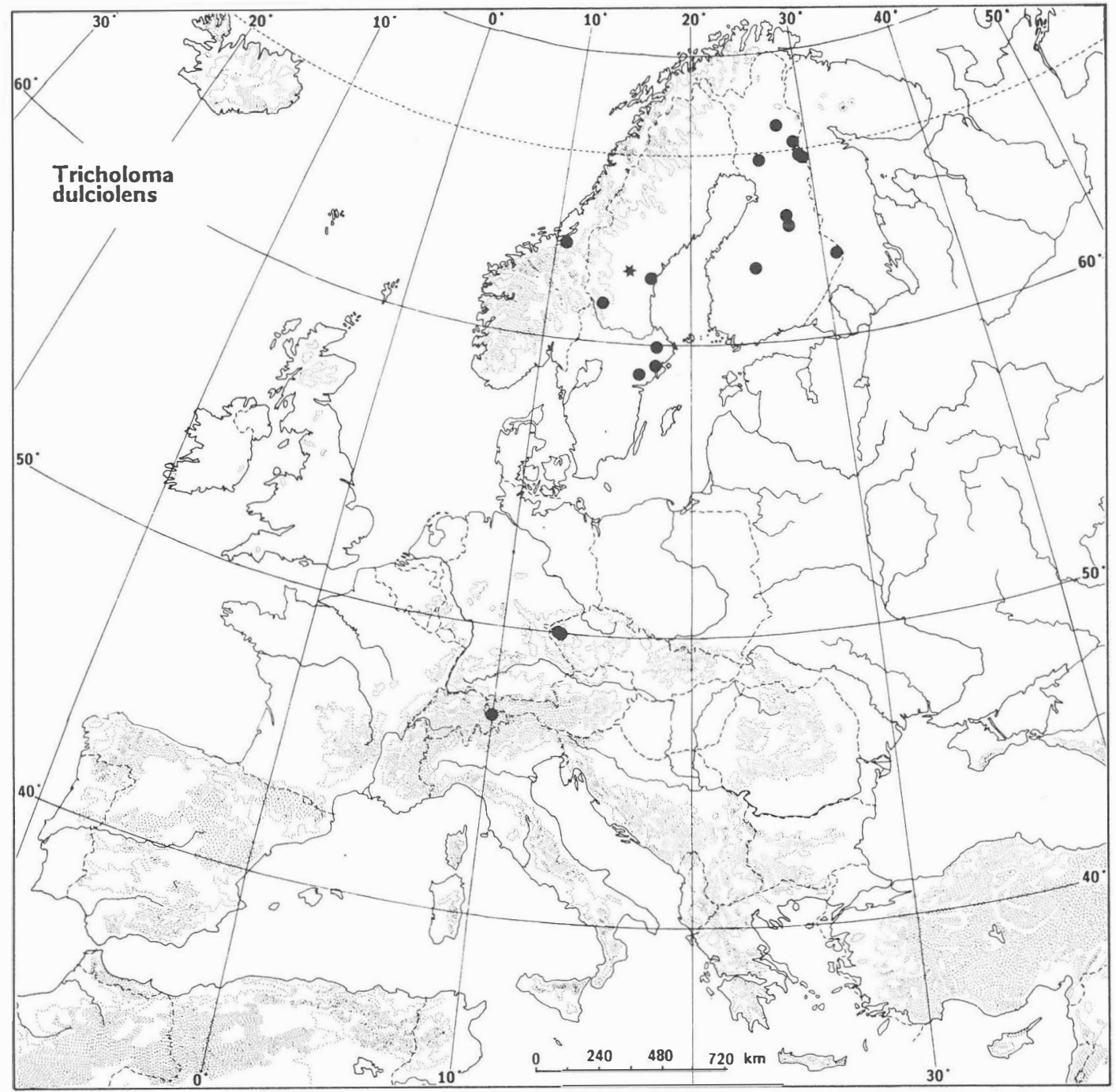

Fig. 9. Distribution of Tricholoma dulciolens in Europe and adjacent North Africa according to the material examined. Astcrisk indicates the type locality.

\section{References}

Albertini, I.B. \& Schweinitz, L.D. 1805: Conspectus fungorum Lusatiae superioris agro niskiensi crescentium. - 376 pp., 12 pls. Lipsiae.

Barla, J.B. 1859: Les Champignons de la province de Nice et principalement les espèces comestibles, suspectes ou vénéneuses, dessinés d'après naturc. - 138 pp., 48 pls. Nice (cited by Bresadola 1927).

- 1888: Les Champignons des Alpes Maritimes: Flore mycologique illustrée. $-80 \mathrm{pp}$., $64 \mathrm{pls}$. Nice.

Blytt, A. 1905: Norges hymenomyceter. - VidenskabsSelsk. Skrifter 1. Math.-nat. KI. 1904 no. 6:1-164.
Bon, M. 1976: Tricholomes de France et d'Europe occidentalc 4. - Doc. Mycol. 6:165-304.

- 1984: Les Tricholomes de France et d'Europe occidentale. -324 pp. Paris.

- 1987: The mushrooms and toadstools of Britain and Northwestem Europe. - 352 pp. London.

Bresadola, J. 1927: Iconographia mycologica 1. - Pls. 1-50. Mediolani.

Britzelmayr, M. 1895: Zur Hymenomycetenkunde. 1-2. 55 pls., 45 pls. Berlin (cited in the following).

- 1898: Revision der Diagnosen zu den von M. Britzelmayr 
aufgestellten Hymenomyceten-Arten. - Bot. Centralbl. 5:129-135.

Cetto, B. 1980: Der grosse Pilzführer 2. 3rd ed. - 729 pp. Trento.

Dähncke, R.M. \& Dähncke, S.M. 1980: 700 Pilze in Farbfotos. - 686 pp. Stuttgart.

Eriksson, C., Lindberg, R., Lindström, H., Muskos, S., Tedebrand, J.O. \& Wimo, J.O. 1985: Medelpads svampar. En sammanfattuning av vår nuvarande kunskap om svampamas förekomst och utbredning i landskapet. - 239 pp. Sundsvall.

Favre, J. 1960: Catalogue descriptif des champignons supérieurs de la zone subalpine du Parc National Suisse. Ergebn. Wiss. Unters. Schweiz. Nationalparks 4:323-610, 1-8 pls. Upsaliae.

- 1874: Hymenomycetes Europaei sive Epicriseos systematis mycologici. - 755 pp. Upsaliae.

Gillet, C.C. 1874: Les hyménomycètes ou description de tous les champignons qui croissent en France. - Alençon.

Gulden, G. 1969: Musseronflora. - 96 pp. Oslo.

Holmgren, P.K., Keuken, W. \& Schofield, E.K. 1981: Index herbariorum 1. The herbaria of the world. 7th ed. - Regnum Vegetabile 106:1-452.

Ito, S. \& Imai, S. 1925: On the taxonomy of Shii-take and Matsu-take. - Bot. Mag. 39:319-328, pl. 6.

Imazeki, R. \& Hongo, T. 1965: Coloured illustrations of fungi of Japan 1. - 181 pp. Osaka.

Korhonen, M. 1986: Uusi sienikirja. - 318 pp. Helsinki.

Kost, G. 1981: Vergleichende morphologische, anatomische und feinstrukturclle Merkmalsstudien an Arten der Gattung Tricholoma (Fr.) Staude, Scktion Genuina (Fr.) Sacc.

Kreisel, H. (ed.) 1987: Pilzflora der Deutschen Demokratischen Republik. Basidiomycetes (Gallert-, Hut- und Bauchpilze). - 281 pp. Jena.

Krieglsteiner, G. 1981: Verbreitung und Ökologie 150 ausgewählter Blätter) und Röhrenpilze in der Bundesrepublik Deutschland (Mittcleuropa). — Zeitschr. Mykol. Beih. $3: 1-276$.

Lanzoni, G. 1988: Tricholoma caligatum (Viviani) Ricken. - Riv. Micol. Boll. Assoc. Micol. Bresadola. 31(3-4): cover \& inside front cover.

Lundell, S. \& Nannfeldt, J.A. 1949: Fungi Exsiccati Suecici, Praesertim Upsalienses. Fasc. 35-36. Nos. 17011800. - 45 pp. Uppsala.

Maire, R. 1915: Schedae ad Mycothecam Boreali-Africanam. Fasc. 5. - Bull. Soc. Hist. Nat. Afrique Nord VII: 139-156.

Maire, R. \& Werner, R.G. 1937: Fungi Maroccani. Catalogue des champignons connus jusqu'ici au Maroc. Mćm. Soc. Sci. Nat. Maroc 45:1-147.

Malençon, G. \& Bertault, R. 1975: Flore des champignons supérieurs du Maroc 2. - 539 pp. Rabat.

Marchand, A. 1986: Champignons du Nord et du Midi 9. Tricholomes. -273 pp. Pcrpignan.

Michael, E., Henning, B. \& Kreisel, H. 1979, 1987: Handbuch für Pilzfreunde 3. 2nd ed. (1979), 3rd ed. (1987). - $484 \mathrm{pp}$. Stuttgart.

Moreno, G., Manjon, J. \& Zugaza, A. 1986: La guia de incafo de los hongos de la peninsula Iberica. 2. -
665-1278 pp. Madrid.

Moser, M. 1983: Die Röhrlinge und Blätterpilze. - In: Gams, H. (ed), Kleine Kryptogamenflora Ilb/2.2. 5th ed. -533 pp. Stuttgart.

Moser, M. \& Jülich, W. 1987: Colour atlas of Basidiomycetes. 4. -117 pls. Stuttgart.

Neuhoff, W. 1960: Die Ringritterlinge Tricholoma robustum (Alb. u. Schw. ex. Fr.) und T. focale (Fr.). Westf. Pilzbriefe 2:73-78.

Pace, G. 1978: Kleiner Pilzatlas mit 299 Farbtafeln und 69 Zeichnungen von L.R. Maggiora. - 350 pp. Verona.

Pilát, A. 1950: Tř̌ní houby v Cínè a v Japonsku. - Česká Mykol. 4:33-39.

Pilát, A. \& UŚák, O. 1961: Mushrooms and other fungi. - 160 pls. London.

Pomerleau, R. 1980: Flore des Champignons au Quebec et régions limitrophes. -653 pp. Ottava.

Ricken, A. 1915: Die Blätterpilze (Agaricaceae) Deutschlands und der angegrenzenden Länder, Oesterreichs und Schweiz. - 480 pp., 112 pls. Leipzig.

Riva, A. 1988: Tricholoma (Fr.) Staude. - Fungi Europaei. 3. $618 \mathrm{pp}$. Saronno.

Shtshukin, G. 1981: Some species of Boletales, Agaricales and Russulales new for Estonia. - Folia Crypt. Estonica 13:1-8.

Singer, R. 1986: The Agaricales in modem taxonomy. 4th rev. ed. VIII, 981 pp., 88 pls. Koenigstein.

Smarda, F. 1950: Nové nálezy vyššich hub v Československu. — Česká Mykol. 4:21-22.

Smith, A.H. 1979: The stirps Caligata of Armillaria in North America. - Sydowia, Beih. 7. 368-377.

Societat Catalana de Micologia (ed.) 1985: Bolets de Catalunya. IV. Col-lecció. - 50 pls. Barcelona.

Stangl, J. \& Bresinsky, A. 1967: Beiträge zur Revision M. Britzelmayrs "Hymenomyceten aus Südbayem" 6. Die Gattungen Armillariella, Tricholoma und Dermoloma (Tricholomataceae) in der Augsburger Umgebung. Zcitsch. Pilzkunde 33:32-40.

Svrcek, M., Kubicka, J., Erhart, J. \& Erhart, M. 1981: Der Kosmos-Pilzführer. Die Pilze Mitteleuropas in 448 Farbfotos. - 296 pp. Stuttgart.

Tominaga, Y. 1978: Tricholoma matsutake. - In: Chang, S. \& Hayes, W. (ed), The biology and cultivation of edible mushrooms: 683-697. London.

Ulvinen, T. (ed.) 1975: Suursieniopas. - 359 pp. Helsinki.

Ulvinen, T., Ohenoja, E., Ahti, T. \& Alanko, P. 1981: A check-list of the fungi (incl. lichens) of the Koillismaa (Kuusamo) biological province, N.E. Finland. - Oulanka Reports 2:1-63.

Urbonas, V., Kalamees, L., Lukin, V. 1986: Conspectus florum Agaricalium fungorum (Agaricales s.l.) Lithuaniae, Latviae et Estoniae. - 139 pp. Vilnius.

Viviani, D. 1834: I Funghi d'Italia e principalmente le loro specie Mangereccie, velenose, o sospette descritte ed illustrate con tavole disegnate, e colorite dal vero. $-64 \mathrm{pp}$., 60 pls. Genova.

Zeller, S.M. \& Togashi, K. 1934: The American and Japanese matsu-takes. - Mycologia 26:544-558. 